\title{
THE EFFECTS OF ALTRUISM AND RELATIONSHIP CONFLICT ON ORGANIZATIONAL LEARNING
}

\begin{abstract}
In a turbulent, competitive and changing environment, organizational learning capability has been recognized as an essential means with which to achieve long-term organizational success. For this reason, organizations have sought to create the necessary conditions for the development of this capability. However, there is not such a wide consensus about how managers can promote organizational learning. Accordingly, this article aims to identify some antecedents of organizational learning capability. More specifically, prompted by a recent paradigm shift in the organizational sciences, we propose altruism and relationship conflict as antecedents of organizational learning capability. To test our hypotheses we used structural equations to analyze data from a survey of Spanish firms with recognized excellence in human resource management. The results indicate that in these firms, altruism facilitates organizational learning capability both directly and indirectly (through relationship conflict).
\end{abstract}

Keywords: altruism; organizational learning; organizational learning capability; relationship conflict 


\section{Introduction}

In a competitive environment characterized by market globalization, greater complexity and increasing changes, organizational learning has been considered as one of the strategic means for achieving long-term organizational success and a key indicator of an organization's effectiveness and potential to innovate and grow (Chiva and Alegre, 2009b; Jerez-Gómez et al., 2005). Furthermore, firms with the capacity to learn stand a better chance of sensing, acting upon, and adapting to a fast-changing and dynamic environment (Camps et al., 2011; Chiva et al., 2007).Consequently, the concept of organizational learning capability, defined as the organizational and managerial characteristics that facilitate the organizational learning process or allow an organization to learn, has expanded greatly over the last few years, both in the field of research and among practitioners (Chiva and Alegre, 2008; Chiva et al., 2007). Likewise, five facilitating factors appear to explain this concept (Chiva et al., 2007): experimentation, risk taking, interaction with the external environment, dialogue and participative decision making.

Organizational learning capability is based on a learning culture that promotes the acquisition, creation, and transfer of knowledge as fundamental values (Camps and Rodríguez, 2011). The development of new knowledge derived from organizational learning reduces the likelihood that a firm's competencies will become outdated, enabling the competencies to remain dynamic and thus favoring improvement in performance (García-Morales et al., 2012). Accordingly, one of the most important issues for organizations is how to generate environments that have a high capacity for organizational learning.

However, despite the increasing importance of organizational learning for creating competitive advantage, there is not such a wide consensus about how managers can efficiently develop organizational learning capability (Jerez-Gómez et al., 2005; JerezGómez et al., 2007). Certain management practices and internal circumstances can help or hinder this process; it is therefore necessary to identify the specific conditions required to improve learning (Goh, 2003). Indeed, some authors (e.g., Akgün et al., 2007; Jerez-Gómez et al., 2005; Van Grinsven and Visser, 2011) have suggested that future research should explore the different antecedents of organizational learning capability. 
Furthermore, although past research in organizational learning has focused extensively on individual learning in organizational contexts, more recent literature has shifted its focus from the individual to the social interactions between people, illustrating the importance of social aspects of learning (Atwood et al., 2010). As leaders play a critical role in both structuring and modeling these interactions, leadership style has been described as one of the most important means for developing organizational learning or organizational learning capability (Atwood et al., 2010; Berson et al., 2006; Vera and Crossan, 2004). More specifically, the presence of supportive, transformational, spiritual or authentic leadership has been described as an essential way to develop organizational learning (Aragón-Correa et al., 2007; Berson et al., 2006; Fry et al., 2005; Gardner et al., 2005; Llorens-Montes et al., 2005) and a key common feature of these leaders is that they are altruistically motivated, demonstrating a genuine care and concern for people (Brown and Treviño, 2006).

Indeed, lack of sustainability, increasing inequity, escalating environmental problems, the current global financial crisis, and growing interdependence in today's world all call for a serious rethink about current business strategies (Rynes et al., 2012; Pirson and Lawrence, 2010; Pirson and Turnbull, 2011) toward a more altruistic approach. In consequence, a number of scholars have noted a paradigm shift in organizational sciences, management theory and practice over the last few years (e.g., Karakas, 2010; George, 2013; Pirson and Lawrence, 2010; Rynes et al., 2012). This paradigm shift in management includes a change from self-centeredness to interconnectedness and moving from self-interest to service and stewardship (Karakas, 2010).

Consistent with this paradigm shift, this more altruistic approach might indicate that selfless concern or care for others positively influences organizational learning. In fact, some studies have also proposed that organizational citizenship behavior (OCB), which includes altruism as an essential dimension, is positively related to organizational learning (Chang et al., 2011; Somech and Drach-Zahavy, 2004). OCBs are employee work behaviors of a discretionary nature that are not part of employees' formal role requirements such as helping others or going beyond the normal expectations on their job (Organ et al., 2006). However, although there is evidence of a relationship between such employee behaviors and organizational learning, some scholars (e.g., Bolino et al., 2004; Bolino et al., 2013; Vigoda-Gadot, 2006) have also noted that, in some cases, participation in OCB might stem from self-serving motives (e.g., impression 
management) or may be not really voluntary and even compulsory. Accordingly, we consider it appropriate to explore if genuine discretionary behaviors in which employees helping others with work-related issues, namely altruism, may also be related to organizational learning capability.

On the other hand, altruism has been proposed as an important inhibitor of relationship conflict (Eddleston and Kellermanns, 2007; Kellermanns and Eddleston, 2004). However, this effect has only been found in the context of family firms. And, as Kellermanns and Eddleston (2004) noted, the uniqueness of relationships in family firms could mean that the effects of altruism on relationship conflict may not be the same in non-family firms. These authors therefore call for further research to determine whether these effects can also be attributed to non-family firms, thereby improving our understanding of them. Accordingly, we suggest that altruistic behaviors bring about an emotional and effective bond between individuals that curtails personal discrepancies and incompatibilities. Consequently, altruism may reduce relationship conflict in organizations. In turn, relationship conflict may impede certain behaviors that are essential to the development of learning within organizations. We propose that relationship conflict may have adverse effects on the five core factors that facilitate organizational learning capability identified by Chiva et al. (2007). Thus, if relationship conflict is absent, individuals would be more predisposed to experiment, take risks, interact with the environment, dialogue, and participate in decision making. To understand the specific circumstances under which altruism affects organizational learning capability, relationship conflict could be introduced as a mediator variable that helps to offer a better explanation of this relationship.

For these reasons, we aim to ascertain whether altruism within organizations can facilitate organizational learning capability, and whether this relationship might be explained by relationship conflict. Despite the growing theoretical importance of concepts such as conflict and organizational learning capability, there is no empirical evidence establishing how these variables are related simultaneously with altruism. Indeed, the study of altruism within organizational contexts has been somewhat marginalized in the organizational literature. As Kanungo and Conger (1993, p. 37) mentioned, "the game of business is played in a competitive arena and hence few expect business people to be altruistic". Under a value system driven by the forces of capitalism and a utilitarian moral philosophy that fosters individualism and self-interest, 
underpinned by the belief that success depends on a measure of individualism and individual competition, altruism has not been perceived as important or as beneficial in the world of business (Kanungo and Conger, 1993). Consequently, the study of altruism within organizational contexts has been somewhat marginalized in the organizational literature, with the result that the relationships between individual and organizational aspects of altruism have not been clearly defined (Healy, 2004). To examine this gap in the research, we carried out a quantitative analysis of a sample of Spanish firms with recognized excellence in human resources management. We select this sample of firms because we think that they set a benchmark for many other organizations.

Following this introduction, we briefly review the concepts of altruism, organizational learning capability and relationship conflict, and propose three hypotheses on their relationships. We then describe the methodology used in the study. Finally, we report the results, and discuss the implications and limitations of the study, together with proposals for future research.

\section{Conceptual framework and hypotheses}

\section{Altruism}

Altruism can be defined as the enduring tendency to think about the welfare and rights of other people, to feel concern and empathy for them, and to act in a way that benefits those (Van Emmerik et al., 2005). Altruists have irreducible other-directed ends. Simmons (1991, p. 3) also provides a useful definition: "altruism (1) seeks to increase another's welfare, not one's own; (2) is voluntary; (3) is intentional, meant to help someone else; and (4) expects no external reward". Within organizational contexts, altruism is defined as all the "discretionary behaviors that have the effect of helping a specific other person with an organizationally relevant task or problem" (Organ, 1988, p.8). Altruism in organizations includes actions such as "helping others who have been absent," "orienting new people even though it is not required," "helping others who have heavy workloads," and "assisting [the] supervisor with his or her work" (Smith et al., 1983, p. 657).

Therefore, altruism is assumed as a feeling of empathy and concern for others and includes all discretionary behaviors which involve voluntarily helping others with work- 
related issues seeking to increase another's welfare, not one's own, and without expecting any reward. It should be noted that although the literature has predominantly considered altruism at the individual level, we propose to assess it at the organizational level in order to ascertain the overall presence of altruism in the organizational context.

\section{Organizational learning capability}

The concept of organizational learning capability (Chiva and Alegre, 2009b; Chiva et al., 2007; Dibella et al., 1996; Goh and Richards, 1997; Jerez-Gómez et al., 2005) stresses the importance of the facilitating factors of organizational learning or an organization's propensity to learn. Chiva et al. (2007) identified five core factors that facilitate organizational learning: experimentation, risk taking, interaction with the environment, dialogue, and participative decision making.

According to Chiva et al. (2007), experimentation involves trying new things, being curious about how things work, implementing changes in work processes or finding innovative solutions to problems, based on the possible use of different methods and procedures. Acceptance of risk entails the possibility of errors and failures. Several authors have highlighted the importance of taking risks and accepting mistakes in ensuring that organizations learn (Popper and Lipshitz, 2000; Ulrich et al., 1993). On

the other hand, relationships and connections with the environment are crucial to organizations. Thus, the environment is identified as a trigger for organizational learning (Hedberg, 1981). Furthermore, dialogue is a vital factor in the organizational learning process (Dixon, 1997). Authors from the social perspective in particular (Brown and Duguid, 1991; Weick and Westley, 1996) stress the importance of dialogue and communication for organizational learning. Participative decision making refers to the level of influence employees have in the decision-making process (Chiva et al., 2008). Recent studies have underlined the importance of participative decision making in order for organizations to learn (Scott-Ladd and Chan, 2004; Chiva et al., 2007). 


\section{Relationship conflict}

Workplace conflict emerges when one party -be it an individual or a group of individuals- perceives its goals, values, or opinions being thwarted by an interdependent counterpart (De Dreu, 2008). Within organizations, perceived differences and opposition evolve around work- and task-related issues or around socio-emotional and relationship issues (De Dreu and Beersma, 2005; Jehn, 1995). Accordingly, the literature on conflict makes a clear distinction between task (or cognitive) and relationship (or emotional) conflict.

Task conflict refers to conflicts which arise over substantive issues (such as differences of opinion or ideas about the correct way to approach a task or solve a problem), whereas relationship conflict refers to socio-emotional or interpersonal disagreements that are usually associated with feelings of annoyance, tension and animosity (Jehn, 1995). Thus, relationship conflict is a kind of conflict with a strong personal and emotional component, characterized by friction and personality differences among individuals, such as interpersonal style, attitudes and preferences and personality (De Dreu and Van Vianen, 2001). It should be kept in mind that although relationship conflict is typically measured at group or dyadic level, we examine the concurrence of these feelings or interpersonal disagreements in the organization by verifying the common existence of relationship conflict at the organizational level.

\section{Hypotheses}

In accordance with the definitions given in the previous section on altruism, organizational learning capability and relationship conflict, we present the theoretical model shown in Figure 1. Our model proposes that the effect of altruism on organizational learning capability is partially mediated by relationship conflict.

As pointed out by organizational learning literature, two main explanations appear to have been put forward for how organizations learn (Chiva and Alegre, 2009): the individual and the social views. The individual view considers learning as an individual phenomenon and consequently understands that organizations learn through individuals (Huber, 1991; Simon, 1991); alternatively, the social view considers learning as a social phenomenon and consequently understands that organizations learn through 
communities and groups (e.g., Brown and Duguid, 1991). In this regard, altruism in organizations involves interaction between individuals and active participation with others, which falls into the social perspective, and also individual experiences, which are more oriented to the individual perspective. Moreover, relationship conflict involves interpersonal incompatibilities or disputes among group members or individuals resulting from daily interactions occurring in the workplace, which corresponds to the social view of organizational learning. Therefore, based on these two main perspectives for how organizations learn, we address how altruism and relationship conflict may be related to organizational learning capability.

Altruism and organizational learning capability: the inclusion of relationship conflict as a mediating variable in the relationship

As current management theory is largely informed by economics, it draws substantively from neoclassical theories of human beings (Ghoshal, 2005; Pirson and Lawrence, 2009). Accordingly, economics-based management theories view the human being as a materialistic utility maximizer who values individual benefit over group and societal benefit, a 'homo economicus' who engages with others only in a transactional manner to fulfill his or her interests and who is amoral, values short term gratification, and often acts opportunistically to further personal gain (Pirson and Turnbull, 2011; Pirson and Lawrence, 2010).

However, new scientific discoveries, renewed economic theories and resurrected philosophical approaches are leading scholars to reevaluate the assumptions about human motivations and behavior. In this regard, as an alternative to the economistic paradigm, some authors have proposed a humanistic paradigm (Melé, 2009; Pirson and Lawrence, 2010; Spitzeck et al., 2009; Pirson and Turnbull, 2011). In contrast to economics-based management theories, this humanistic paradigm views the individual as a relational person who is intrinsically motivated to serve humanity through his or her actions (Pirson and Turnbull, 2011; Pirson and Lawrence, 2010). As such, human beings are not only motivated and interested in maximizing their own utility, but in balancing their own interests with those of the people around them (Dierksmeier and Pirson, 2008; Pirson and Turnbull, 2011). 
Contrary to self-interested theories, this alternative paradigm in organizational sciences, management theory and practice has other-interest as opposed to self-interest at its core, and individuals are seen as more collaborative, empathetic, altruistic, and motivated by caring about the well-being of others (Brown et al., 2012; Rynes et al., 2012). Undoubtedly, this new humanistic paradigm needs to be refined and more theoretical and empirical contributions are required to develop the consequences that this alternative view has for business organizations. However, considering this more humanistic view can provide a more accurate picture of human nature (Melé, 2009; Pirson and Lawrence, 2010). Based on this humanistic approach, we aim to uncover the consequences of altruism in organizational settings, specifically, for organizational learning capability.

In the next few paragraphs we relate altruism to Chiva et al.'s (2007) five dimensions of organizational learning capability. Because altruism is characterized by feelings of concern and empathy for others (Cialdini et al., 1997), it may help us consider and more easily understand other people's views or the decisions they take. Consequently, altruism in organizations may help ensure that workers' decisions or views are taken into account more easily, thus increasing the level of influence that employees have in the decision-making process. Altruism may therefore promote a participatory and democratic decision-making system that can facilitate learning.

On the other hand, Piliavin and Charng (1990, p. 33) claim there is some evidence that propensities to take risks may be related specifically to willingness to engage in altruistic acts. These authors provide evidence to explain how altruistic individuals are more predisposed to take risks. They give examples indicating that these individuals are characterized by "a spirit of adventurousness" and are more likely to be risk-takers than other non-altruistic individuals. Altruistic behaviors seek to increase the welfare of others or benefit another, but not oneself, even if it involves a personal cost or sacrifice, without expecting any reward (Monroe, 1996; Simmons, 1991). Hence, altruism benefits others, often involving a risk or sacrifice that goes against the personal interests of the individual (Kaplan, 2000). Altruism therefore means being prepared to make sacrifices for the benefit of others, and accepting the risk that no gain or even a cost may be incurred in exchange. Personal sacrifice for others involves exerting effort and taking risks to serve others (Puffer and Meindl, 1995). Altruistic individuals therefore willingly assume risks that others try to avoid and seem to be more inclined to engage in risky 
behaviors. Thus, altruism in organizations may be related to the propensity to take risks (Piliavin and Charng, 1990), such that a person who behaves altruistically will be more predisposed to assume risks.

Moreover, altruism encompasses spontaneous behaviors that help a specific individual in a particular organizationally germane task, difficulty, or issue (Deluga, 1995). Altruism involves going above and beyond job requirements to help others with whom one comes into contact (Organ et al., 2006) and includes activities such as voluntarily helping colleagues on a project in which one is not directly involved or without being asked to do so, assisting someone with a heavy workload, offering to help others accomplish their work or volunteering for additional tasks. Therefore, altruism in organizations leads workers to take on activities that go beyond those formally required by their job, which may enable individuals to experiment with new processes or behaviors.

Furthermore, individuals in organizations behave altruistically when helping or cooperating with another worker voluntarily on a task (Fassina et al., 2008). Hence, altruism entails personal contact and cooperation between parties. These personal and cooperative interactions prompted by altruism may facilitate information exchange and communication. In fact, the literature reflects that altruism is positively associated with cooperation (Schulze et al., 2003; Yen and Niehof, 2004), information exchange (Daily and Dollinger, 1992) and communication (Gersick et al., 1997; Schulze et al., 2003). Consequently, we propose that by promoting interactions and relations with others, a climate of altruism in organizations may foster dialogue and communication between individuals, and also open up possibilities for the interaction with the external environment that is crucial to organizational learning.

Thus, altruism in organizations seems to be closely associated with the dimensions or factors that facilitate organizational learning. A climate of altruism appears to encourage risk taking, participatory decision making, experimentation, interaction with the environment, and dialogue. Accordingly, we propose that altruism could enhance organizational learning capability.

However, as Bolino et al. (2013) claim, it is necessary to examine the mediating processes through which different types of OCB such as altruism may influence other organizational variables. Certain contextual variables may explain and condition the 
effects of altruism in organizations on other larger organizational outcomes (Bolino et $a l ., 2013)$. Altruism is characterized by perspective taking and by feeling concern and empathy for the welfare and rights of other people (Batson, 1991; Van Emmerik et al., 2005). It helps to create an emotional and affective bond between individuals (Islam et al., 2012), which may lead them to perceive fewer interpersonal disaffections and incompatibilities. Altruism may therefore reduce relationship conflict in organizations.

In turn, by impeding open communication, openness to new ideas, the assimilation and processing of information, active participation and cooperation, and listening and constructive dialogue between people (Amason et al., 1995; Greer et al., 2008; Griffith et al., 2003; Panteli and Sockalingam, 2005), relationship conflict may impede organizational learning. Conversely, the lack of relationship conflict between individuals may encourage certain behaviors that facilitate organizational learning capability such as risk taking, participatory decision making, experimentation, interaction with the environment, and dialogue (Chiva et al., 2007). Therefore, altruism may reduce relationship conflict, which in turn could enhance learning in organizations.

According to these arguments and proposals, altruism may then be understood as a factor that can directly increase organizations' learning capability and relationship conflict could act as an explanatory mediating variable in this relationship. We therefore propose the following hypothesis:

Hypothesis 1: The relationship between altruism and organizational learning capability is partially mediated by relationship conflict.

\section{$\underline{\text { Altruism and relationship conflict }}$}

Process models of conflict suggest that the degree and quality of exchanges between parties are important determinants of relationship conflict (Korsgaard et al., 2008). Several aspects concerning the quality of social interactions have been posited as antecedents of conflict, including communication, fair treatment, interference, and the overall quality of relationships (Korsgaard et al., 2008). Thereby, high-quality exchange relationships based on interpersonal helping and concern for the welfare of others may determine the level of conflict in a relationship. In fact, as Somashekhar et al. (2011) 
claim, altruistic behaviors encourage the development of healthy personal relationships in which individuals trust each other and where fewer conflicts and disputes arise.

According to Eddleston and Kellermanns (2007), when altruism is low, the likelihood of opportunistic behavior raises the probability of relationship conflict. These authors found altruism to be an important inhibitor of relationship conflict in family firms. However, as Kellermanns and Eddleston (2004) mentioned, "the intensity of altruism that can be expected among family members is higher thereby making the effects of altruism on relationship conflict theoretically distinct in family firms". We therefore aim to examine and explain the effects of altruism in non-family firms where it may be not so predominant and members are not so bound by strong emotional bonds.

As previously stated, relationship conflict is the perception of personal animosities and incompatibility that includes a strong personal, affective and emotional component. Relationship conflict is related to differences among individuals in personal concerns, such as personality differences and feelings of dislike such as annoyance, frustration, and irritation (Jehn, 1995; Jehn and Mannix, 2001). In this regard, individuals' capacity to understand and accept these differences may reduce the likelihood of such conflicts arising.

Altruism arises from a state of consciousness in which we realize that we are all interrelated - that our interactions affect others positively or negatively and that altruism enhances relationships, while nepotism and egoism can be destructive (Morrison and Severino, 2007). Altruism includes the ability to be empathetic and to understand the perspective of others (Batson, 1991). It entails a belief in the importance of the welfare and just treatment of others, and is characterized by perspective taking and by empathy. Likewise, perceiving another person's empathy for oneself is likely to increase affiliation and strengthen the emotional bond with that person (Vignemont and Singer, 2006). In fact, according to Islam et al. (2012), altruism results in interconnections and creates a link or bond between employees. People feel close and connected to others whom they perceive to be responsive and supportive of their needs (Lemay et al., 2007). Hence, the empathy and understanding of the interests of others that accompany altruism increase the likelihood of an emotional bond being established with others. Personal animosities and incompatibilities may be less likely to arise when affective and 
emotional bonds are created with others. Therefore, altruistic behaviors may help prevent relationship conflict from arising. This leads us to the following hypothesis:

Hypothesis 2: Altruism is negatively related to relationship conflict.

\section{$\underline{\text { Relationship conflict and organizational learning capability }}$}

One of the most outstanding features of conflict, a phenomenon omnipresent in organizational life, is that it is a double-edged sword that can have both functional and dysfunctional effects on individuals, groups and organizations (Panteli and Sockalingam, 2005). Research by Jehn (1994, 1995), Amason (1996) or De Dreu and Weingart (2003) attributes this double-edged effect to different dimensions of conflict. Thus, while moderate levels of task conflict are considered to be largely functional (De Dreu, 2006; Jehn, 1995), relationship conflict is understood as predominantly dysfunctional (e.g., Amason, 1996; De Dreu and West, 2001; Olson et al., 2007).

The literature on these dysfunctional effects reports that relationship conflict impedes goodwill and understanding between members and makes them less open to the workrelated ideas of their colleagues (Greer et al., 2008). In this regard, Panteli and Sockalingam (2005, p. 603) note that relationship conflicts "inhibit individuals' cognitive functioning in assessing new information provided and processing complex information, encourage stereotype listening and induce the freezing out of iconoclasts from important discussions". The literature also suggests that members involved in a relationship conflict may work less cooperatively (Griffith et al., 2003). Moreover, relationship conflict fosters cynicism, distrust, avoidance and weakens relationships, which in turn curtails open communication and learning (Amason et al., 1995; Panteli and Sockalingam, 2005). Hence, relationship conflict may limit organizational learning.

Accordingly, we propose that relationship conflict may be negatively associated with the organizational learning facilitating factors suggested by Chiva et al. (2007), namely, experimentation, risk taking, dialogue, interaction with the external environment and participative decision making.

Firstly, individuals who are distrustful of or apathetic toward one another are not willing to engage in the types of discussions necessary to synthesize their different perspectives 
(Amason et al., 1995). Amason et al. (1995) also affirm that when disagreements are personalized, individuals cease to be active participants in the decision process. Interpersonal conflicts therefore curtail the active participation of those involved in taking decisions, and in consequence interpersonal discrepancies or disaffections make the decision-making process much less participative. The absence of relationship conflict in organizations will therefore foster the participative decision making that is crucial to organizational learning (Chiva et al., 2007).

Moreover, when individuals perceive discrepancies, incompatible wishes or desires, it can result in antagonistic and hostile interaction among group members (Chuang et al., 2004). When this situation arises the individuals involved in the conflict are likely to be less willing to interact, and as a result, dialogue and communication between them could suffer. Therefore, the absence of relationship conflict in organizational climate could promote a greater willingness to open communication and dialogue. Thus, a relationship conflict in organizations may be negatively associated with dialogue, which is included as another facilitating factor or dimension of organizational learning (Chiva et al., 2007).

On the other hand, scholars have emphasized the importance of observing, opening up to and interacting with the external environment in promoting organizational learning (e.g., Chiva et al., 2007; Goh and Richards, 1997). Since relationship conflict limits individuals' information processing ability (De Dreu and Weingart, 2003; Simons and Peterson, 2000), members with interpersonal incompatibilities may be distracted from observing and interacting with the external environment. Moreover, in a relationship conflict people focus much of their efforts and attention on discussing, resolving or ignoring their personal incompatibilities, discrepancies and disaffections (Jehn, 1995). As a result, relationship conflict may prevent organizational members from focusing on the firm's immediate environment and establishing relations and connections with it. Hence, the absence of such conflicts in organizational climate may encourage individuals to interact more easily with their immediate environment. Therefore, relationship conflict in organizations may increase the interactions that a firm maintains with its external environment that are crucial for organizational learning (Chiva et al., 2007). 
According to Jehn and Bendersky (2003), interpersonal conflict makes members less receptive to the ideas of other group members, some of whom they may not like or who may not like them. Therefore, relationship conflict limits cognitive processing and reduces the ability of group members to assess new information provided by other members (Jehn and Bendersky, 2003). In consequence, if workers are unable to focus on the real tasks required by their jobs, it is likely that they will be less able to contribute creative and innovative ideas and suggestions that can lead to changes. Because their cognitive capabilities are restricted, individuals in conflict may be less willing to listen, assimilate and accept new ideas. Conversely, people who experience a high degree of connectivity with others create expansive emotional spaces that open possibilities for creativity and trying out new ideas (Losada and Heaphy, 2004; Spreitzer et al., 2005). Thus, the absence of relationship conflict in work environments may increase the opportunities for experimenting with new processes and procedures, or may create a more comfortable atmosphere for workers to put forward new ideas. Mitigating these conflicts in organizations may therefore stimulate organizational learning since experimentation is considered to be an essential condition for organizations to learn (Chiva et al., 2007).

Finally, positive working relationships provide workers with a state of psychological safety in which they feel confident to experiment and take risks (Spreitzer et al., 2005). Psychological safety describes taken-for-granted beliefs that others will respond positively when one exposes one's thoughts, such as by asking a question, seeking feedback, reporting a mistake, or proposing a new idea (Edmondson, 1999). The experience of psychological safety can allow organizational members to relax their guard and engage openly in behaviors for which outcomes are unpredictable (Edmondson and Mogelof, 2006). Therefore, workers who feel safe and connected to each other are more comfortable taking risks, such as trying something new or contributing ideas. In contrast, if they perceive interpersonal incompatibilities and discrepancies, they may refrain from taking risks since they may believe that when they make a mistake others will be likely to respond negatively (e.g., by criticizing or ridiculing). Hence, a climate of interpersonal disaffections and feelings of interpersonal incompatibility may create hostile and distrustful work relationships in which individuals feel uncomfortable taking risks and accepting mistakes. Therefore, we 
suggest that lack of relationship conflict in organizations may encourage risk taking, which is a necessary element for effective organizational learning (Chiva et al., 2007).

Thus, relationship conflict seems to impede certain behaviors that facilitate organizational learning capability such as risk taking, experimentation, participation, dialogue and interaction with the environment. Consequently, we propose the following hypothesis:

Hypothesis 3: Relationship conflict is negatively related to organizational learning capability.

INSERT FIGURE 1 ABOUT HERE

\section{Research methodology}

Data collection and sampling

The empirical study was based on a population of 402 Spanish firms with proven excellence in human resource management. The population was obtained from merging different databases or lists of firms that consider people as a key element of their organizations and are regarded by their workers as good firms to work for, or organizational environments where human resources management is considered important. The databases used were taken from the lists of 'CRF Top Employers', 'Great Place to Work Institute', 'mercoPersonas', and 'Actualidad Económica'. We consider that many other firms could take them as models. Moreover, because the particular qualities and conditions shared by these firms, we believe that the relationships among the variables arising in these working environments can be a subject worthy of in-depth examination.

Each of these firms was sent a pre-designed questionnaire. This questionnaire was addressed to managers with at least two years' experience at the firm, preferably human resources managers. The questionnaire consisted of a total of 28 items measured on a 5point Likert scale, showing the level of agreement or disagreement with the content of 
each item. Before starting the fieldwork, the questionnaire was pretested in order to ensure that the items were comprehensible to the recipients. This was achieved with the cooperation of people from the academic sphere whose research and interest revolve around human resources, as well as various human resources managers from different firms. A total of 251 valid questionnaires were received. The sample obtained therefore represented $62.44 \%$ of the study population, which is considered to be a satisfactory response rate. The number of responses exceeded the minimum threshold of one hundred subjects necessary for the application of structural equation methodology and to test the psychometric properties of the measurement scales (Spector, 1992; Williams et al., 2004). Data were collected between October and December 2010.

\section{Measurement instruments}

Measurement scales were taken from previous studies to measure each of the constructs or dimensions in this research. The three dimensions in this study are altruism, relationship conflict and organizational learning capability.

\section{$\underline{\text { Altruism }}$}

The scale proposed to measure the altruism construct was based on Podsakoff et al. (1990) instrument designed to measure organizational citizenship behavior. This scale includes the five dimensions of citizenship behavior identified by Organ (1988), one of which is altruism. The psychometric properties of the scale used had been analyzed previously and the validity of the measuring instrument was verified. Finally, the authors include a total of five items to measure the 'altruism' dimension. These items were selected to measure the construct in the present study.

\section{Organizational learning capability}

This scale was based on the work of Chiva et al. (2007) and Chiva and Alegre (2009b), which suggests measuring organizational learning as a multidimensional construct bringing together proposals from the social perspective (e.g., Brown and Duguid, 1991; 
Weick and Westley, 1996), the individual perspective (e.g., Hedberg, 1981; Popper and Lipshitz, 2000) and the learning organization (e.g., Pedler, 1997; Ulrich et al., 1993). The individual perspective considers learning as an individual phenomenon and consequently understands that organizations learn through individuals (Chiva and Alegre, 2005; Simon, 1991). The social perspective considers learning as a social phenomenon and therefore understands that organizations learn through communities and groups (Brown and Duguid, 1991; Chiva and Alegre, 2005). The learning organization or prescriptive literature mainly focuses on the development of normative models for the creation of a learning organization (Alegre and Chiva, 2008; Ulrich et al., 1993). This literature (Goh and Richards, 1997; Pedler, 1997) describes a set of actions that ensures learning capability: effective generation of ideas by implementing a set of practices such as experimentation, continuous improvement, teamwork and group problem-solving, observing what others do, or participative decision making. The final scale consisted of five dimensions and a total of 14 items. These dimensions are experimentation, risk-taking, interaction with the external environment, dialogue and participation (Chiva and Alegre, 2009b).

\section{$\underline{\text { Relationship Conflict }}$}

To measure relationship conflict we used Cox's (Cox, 1998; Friedman et al., 2000) organizational conflict scale. Cox's five-item scale focuses on the degree of active hostility found in relationship conflict and contains items such as "much plotting takes place behind the scenes" and "one party frequently undermines the other". Its authors test the validity of the measurement scale and demonstrate that it is a psychometrically valid and viable measurement instrument.

\section{Control variable}

Firm size was included as a control variable in the overall model since it could explain the variation in organizational learning capability. Firm size affects the endowment of significant inputs for the business process such as money, people and facilities (Tippins and Sohi, 2003). Therefore, while larger firms have a greater variety of capabilities, small firms have fewer opportunities to reap the benefits of economies of scale, scope 
and learning (Lepoutre and Heene, 2006;Nooteboom, 1994). Using the variable firm size, each company is classified into one of six categories according to number of employees: fewer than 50 employees (13.9\%), between 50 and 100 employees $(21.5 \%)$, between 101 and 250 employees (25.9\%), between 251 and 500 employees (23.9\%), between 501 and 1,000 employees (10.4\%), and firms with more than 1,000 employees $(4.4 \%)$.

\section{Psychometric properties of the measurement scales}

The psychometric properties of the measurement scales were analyzed to test the dimensionality of the scales measuring the concepts and constructs used in the theoretical model, reliability, validity of content, convergent validity and discriminant validity (see table 1 for the means, standard deviations and correlation factors). Firstly, we analyzed the one-dimensionality of the measurement scales for the altruism and conflict constructs using confirmatory factor analysis (CFA). The CFA indicators reported confirm the one-dimensionality of the altruism construct ( $\mathrm{p}$-value > 0.05; RMSEA $=0.037$; BBNFI $=0.987 ; \mathrm{CFI}=0.996)$ and the relationship conflict construct ( $\mathrm{p}$-value $>0.05 ;$ RMSEA $=0.000 ; \mathrm{BBNFI}=0.991 ; \mathrm{CFI}=1.000)$. The multidimensionality of the organizational learning capability construct was tested with a second-order factor analysis (Chiva and Alegre, 2009b), whose goodness of fit indicators showed a good fit for the model ( $p$-value $>0.05$; RMSEA $<0.05$; BBNFI $>$ 0.90; BBNNFI > 0.90; CFI = 0.987; and $\chi 2 /$ d.f. $=1.20)$ (see figure 2). We used two indicators, namely composite reliability (Fornell and Larcker, 1981) and average variance extracted (Alegre and Chiva, 2008), as well as Cronbach's alpha coefficient (Cronbach, 1951), to test the reliability of the scale. All Cronbach's alpha coefficient values and those for composite reliability are above the minimum acceptable value 0.7 (Nunnally, 1978). In all cases, the average variance extracted shows values greater than or very close to the recommended minimum of 0.5 (Hair et al., 1998; Nunnally, 1978). Content validity was established through the use of previously validated measures and through the pre-test we also carried out. The variables used to measure altruism were those proposed and used by Podsakoff et al. (1990); organizational learning capability was measured using the scale proposed by Chiva et al. (2007); and conflict was measured with Cox's (1998) Organizational Conflict Scale. Convergent validity was 
evaluated using the BBNFI indicator obtained from the confirmatory factor analysis. The values obtained in the BBNFI, as well as the factor loadings for each construct, lie above 0.90 (Ahire et al., 1996) and the factor loadings of the items in each scale had values above 0.4 (Hair et al., 1999), with a t value of more than 1.96 (Anderson and Gerbing, 1982), confirming the convergent validity of the measurement scales. Discriminant validity was assessed using CFA; all correlation coefficients are significant and below 0.9 (Luque, 2000) and the average variance extracted in each dimension is clearly above the square of the correlation of a construct with the others making up the measurement scale (Fornell and Larcker, 1981), verifying the discriminant validity of the model.

As we used subjective evaluation measures, we conducted a Harman's single-factor test (Podsakoff and Organ, 1986; Podsakoff et al., 2003) to check for common method variance and to address the potential social desirability of the responses. The results of the CFA with the 24 indicators loading onto a single factor $(\chi 2(252)=2886.633$; CFI $=$ $0.330 ; \operatorname{RMSEA}=0.175 ; \mathrm{BBNFI}=0.314 ; \chi 2 /$ d.f. $=11.45)$ showed a poor fit, suggesting that the single factor does not account for all of the variance in the data. Consequently, and in accordance with this procedure, we do not consider common method variance to be a problem in our research.

INSERT TABLE 1 ABOUT HERE

INSERT TABLE 2 ABOUT HERE

INSERT FIGURE 2 ABOUT HERE 


\section{Analysis and results}

Table 1 presents the descriptive statistics of the indicators considered in the study. Structural equation modeling (SEM) was used to analyze the theoretical model, using the statistical program EQS 6.1 for Windows. The results confirm an adequate fit of the model with the data used (Satorra-Bentler Chi-Square $=303.048$; degrees of freedom $=$ 267; $p=0.064$; Bentler-Bonnet Non-Normed Fit = 0.984; Comparative Fit Index: 0.986; root mean square error of approximation $=0.023$ ).

Results for the estimated parameters of the model indicate a positive relationship between altruism and organizational learning capability $(\beta 1=0.448, \mathrm{t}=4.284, \mathrm{p}<0.01)$, On the other hand, a negative relationship was found between altruism and conflict ( $\beta 2=$ $-0.192, \mathrm{t}=-2.463, \mathrm{p}<0.01$ ), thus confirming hypothesis $\mathrm{H} 2$, and also showing that conflict has a negative effect on organizational learning capability $(\beta 3=-0.201, \mathrm{t}=$ 2.463, $\mathrm{p}<0.01$ ), confirming hypothesis H3.

\section{INSERT TABLE 3 ABOUT HERE}

\section{INSERT TABLE 4 ABOUT HERE}

In order to test whether conflict mediates in the relationship between altruism and organizational learning capability (hypothesis H1), we followed the procedure described by Beltrán-Martín et al. (2008), which involves estimating two structural models. The first is a direct effects model that tests the effect of independent variables on dependent variables. For this mediation to exist, the coefficient in the direct effects modelreferring to the effect of altruism on organizational learning capability-must be significant for testing of the mediator effect to continue. The second model is a mediated model that includes the mediator variable. This model estimates the effects of altruism on conflict, the impact of conflict on organizational learning capability, and the 
direct effect of altruism on organizational learning capability (Figure 4). To test whether the mediator effect of conflict is partial or total, we compared the mediated model to the constrained model in which the coefficient between altruism and organizational learning capability ( $\beta 1$ in the mediated model) was equal to zero (Beltrán-Martín et al., 2008). This allows us to see whether the mediated model achieves a significant improvement in fit over the constrained model. If conflict causes a total mediator effect, the coefficient of the relationship between altruism and organizational learning capability included in the constrained model will not improve the fit, in the opposite case, the mediation would be partial (Beltrán-Martín et al., 2008). Alternatively, for total mediation to exist, the previously significant altruism-organizational learning capability relationship observed in the direct effects model should be considerably reduced or disappear in the partial mediation model; if it remains significant the mediation would be partial (Beltrán Martín et al., 2008).

The fit indexes for the models are presented in Table 3. In the direct effects model (Figure 3), we confirmed that the coefficient of the relationship of altruism to organizational learning capability is significant $(\beta 1=0.485 ; \mathrm{t}=4.125 ; \mathrm{p}<0.01)$. The $\chi 2$ test of differences between the mediated model and the constrained model showed a statistically significant difference in the $\chi^{2}(\mathrm{p}<0.01)$. The relationship between altruism and organizational learning capability in the mediated model significantly improves the fit of the constrained model, thus evidencing the partial mediation effect of relationship conflict in the model. Additionally, we observe that when relationship conflict is introduced in the equation (in the mediated model), the significant relationship between altruism and organizational learning capability observed in the direct effects model remains in the partial mediation model $(\beta 1=0.448 ; \mathrm{p}<0.01)$. This result can also be interpreted as evidence of a partial mediating effect of relationship conflict in the relationship between altruism and organizational learning capability (Beltrán-Martín et $a l ., 2008$ ). Furthermore, we apply the AIC (Akaike information criterion) test (Akaike, 1974) to compare these two models. According to this criterion, given a set of candidate models for the data, the preferred model is the one with the minimum AIC value. The AIC value of the mediated model is -230.952 , and for the constrained model it is 200.452. The AIC test therefore indicates that the mediated model is preferred over other alternative models. Consequently, altruism affects organizational learning capability both directly and indirectly (through relationship conflict), thus supporting 
hypothesis H1. More specifically, a positive indirect effect $(\beta=0.028 ; \mathrm{t}=1.769)$ is seen between these two variables.

The results therefore verify all the hypotheses proposed in our model (see Table 4). The contribution of the mediated model in terms of the effect of altruism on organizational learning capability lies in the analysis of relationship conflict as a mechanism that mediates this relationship and allows the information provided by the direct effects model to be extended.

\section{INSERT FIGURE 3 ABOUT HERE}

INSERT FIGURE 4 ABOUT HERE

\section{Conclusions}

In recent years some scholars have suggested the need for a paradigm shift in the way organizations are managed and led (e.g., Pirson and Turnbull, 2011; Karakas, 2010; Pirson and Lawrence, 2010; Rynes et al., 2012). Far removed from the neoclassical streams on human motivations that understand people as only pursuing their own benefits, this paradigm shift regards the human being as an individual who is intrinsically motivated to help others through his or her actions (Pirson and Turnbull, 2011; Pirson and Lawrence, 2010). This research aims to link some of those behaviors, like altruism or relationship conflict, to organizational learning capability.

As the study findings show, altruism in organizations is directly linked to the dimensions that facilitate organizational learning suggested by Chiva et al. (2007). 
Hence, altruism is accompanied by a feeling of empathy and concern for others (Cialdini et al., 1997), which makes it easier to understand the perspectives of others and, therefore, for their decisions to be taken in account; as a result the decision-making process becomes more participatory. In addition, when a person behaves altruistically, he or she is willing to make certain sacrifices and accept personal losses (Monroe, 1996; Simmons, 1991). Therefore an altruistic person may be more willing to take risks. Altruism also involves behaving in ways or performing tasks that go beyond the formal requirements of each job (Organ et al., 2006). Hence, altruism could encourage workers to experiment with new processes or activities. Finally, altruism leads to interpersonal interaction and personal contact, which increases the possibilities for communication and exchange of information. Altruism may therefore encourage dialogue and interaction with the external environment. Altruism in organizations, therefore, fosters experimentation, risk taking, dialogue, interaction with the external environment and participative decision making, and consequently promotes learning within organizations. Hence, a climate of altruism in the organization prompts the factors essential to the organizational learning process.

To provide a more accurate explanation of the possible effects of altruism in organizations on organizational learning capability, we introduced relationship conflict as an explanatory variable in this relationship. The results of this study show that altruistic behaviors reduce relationship conflict within organizations. Thus, since altruistic behavior involves understanding the perspective of others and feeling empathy and concern for their welfare (Batson, 1991; Van Emmerik et al., 2005), it can help build affective and emotional connections with others more easily, encouraging the creation of healthy working relationships in which interpersonal disputes and discrepancies are much less likely to arise.

Moreover, as our results show, relationship conflict is negatively related to organizational learning. Relationship conflict generates a hostile, adverse working environment in which individuals feel curtailed and insecure when participating in certain actions or behaviors that improve organizational learning such as experimentation, risk taking, dialogue, interaction with the environment or decision making. Conversely, the absence of interpersonal conflict within organizations helps generate a healthy and friendly working environment in which individuals can feel comfortable and confident when interacting with others and can behave in all the ways 
that enable an organization to learn. Relationship conflict is therefore posited as a mediating variable that explains how altruism improves organizational learning. Thus, altruism in organizations can facilitate organizational learning capability not only directly, but also by reducing relationship conflict.

Although some studies have proposed that organizational learning could be affected by firm size, we did not find a significant relationship between these variables. That is, the size of the firms analyzed in this study does not seem to influence their organizational learning capability. The results of learning in these firms may therefore depend more on other variables such as the implementation of certain HR practices.

Thus, by enhancing organizational learning, the concurrence of a climate of altruism in organizations may therefore offer managers a tool they can use to improve their success in dealing with the challenges of today's uncertain and constantly changing economic environment. Moreover, altruism in organizations promotes a workplace atmosphere in which personal disputes or disaffections are mitigated. Therefore, the presence of a climate of altruism in firms provides the grounds for creating healthy work environments, which may entail positive consequences for employees such as greater job satisfaction and individual well-being, and consequently, may also benefit organizations in terms of increased performance, organizational commitment and organizational health.

Although the concept of altruism in organizations has been marginalized by organizational literature, this study notes its importance in organizational settings and reveals that altruism needs to be incorporated as a core competence among workers. These findings highlight the importance of aid, assistance and service for others as essential employee attributes that organizations should promote and develop. Organizations with altruistic employees may more easily create a workplace climate where people are voluntarily willing to help others with work-related problems, and thus promote the conditions to facilitate what is now a critical feature, namely, organizational learning capability.

By unveiling some antecedents of organizational learning capability, this study offers new strategies for organizations to remain competitive and achieve long-term success in an uncertain and constantly changing economic environment. Moreover, our conclusions suggest the need for a change in the way in which organizations are 
managed, indicating that organizations need to stimulate interconnectedness and collaboration, and avoid an internal climate of competition and self-centeredness, in order to facilitate organizational learning. The findings obtained are consistent with new proposals on management theory that underline a more humanistic and compassionate view of organizations (Karakas, 2010; Pirson and Lawrence, 2010; Pirson and Turnbull, 2011; Rynes et al., 2012), thus setting reformulation and reexamining of business practices and organizational functioning as a major challenge for the future.

It is acknowledged, however, that the study has certain limitations, including the excessive heterogeneity of the sample size and industrial sector. The sample includes firms from various sectors and sizes. So, future research might replicate this study in a single sector and with firms of a similar size. Another limitation concerns the causal direction between the constructs proposed in the model. The cross-sectional nature of our study does not allow inferences about the causality in the observed associations. In any case, this is a common limitation of cross-sectional studies, and longitudinal-type studies are therefore necessary to ascertain the direction of causality in these relationships. Moreover, the firms included in the sample all consider people and human resource management as important. The results are therefore only representative of the study population, namely Spanish firms with recognized excellence in human resources. The generalizability of our results may therefore be limited and should be validated in larger samples of firms where human resource management is not given such great importance. In addition, all the study variables are tested only at the organizational level; future studies might usefully adopt other analysis procedures to investigate the relationships between variables at different levels -individual, group and organizational.

Finally, because learning is understood as an essential factor for organizations to retain long-term competitiveness in the current economic climate (Goh and Richards, 1997; Jerez-Gómez et al., 2005), researchers should continue to explore ways of creating organizational environments with a high learning capability. In addition, in line with the recently proposed paradigm shift, this study demonstrates the benefits of altruistic behaviors for organizations and their members. We therefore suggest that future research should continue to analyze and explore the consequences of altruism in organizations. These conclusions highlight the need to continue applying and developing the new proposals and alternative approaches to come out of management theory in recent years. 


\section{References}

Ahire, S. L., Golhar, D. Y. and Waller, M. A. (1996), "Development and validation of TQM implementation constructs”, Decision Sciences, Vol. 27 No. 1, pp. 23-56.

Akaike, H. (1974), "A new look at the statistical model identification", Automatic Control, IEEE Transactions on, Vol. 19 No.6, pp. 716-723.

Akgün, A. E., Keskin, H., Byrne, J. C. and Aren, S. (2007), "Emotional and learning capability and their impact on product innovativeness and firm performance", Technovation, Vol. 27 No. 9, pp. 501-513.

Alegre, J. and Chiva, R. (2008), “Assessing the impact of organizational learning capability on product innovation performance: An empirical test", Technovation, Vol. 28 No.6, pp. 315-326.

Amason, A. C., Thompson, K. R., Hochwarter, W. A. and Harrison, A. W. (1995), "Conflict: An important dimension in successful management teams", Organizational Dynamics, Vol. 24 No.2, pp. 20-35.

Amason, A. C. (1996), "Distinguishing the effects of functional and dysfunctional conflict on strategic decision making: Resolving a paradox for top management teams", Academy of management journal, Vol. 39 No.1, pp. 123-148.

Anderson, J. C. and Gerbing, D. W. (1982), "Some methods for respecifying measurement models to obtain unidimensional construct measures", Journal of Marketing Research, Vol. 19 No. 4, pp. 453-560.

Aragón Correa, J. A., García Morales, V. J. and Cordón Pozo, E. (2007), "Leadership and Organizational Learning's Role on Innovation and Performance: Lessons from Spain”, Industrial Marketing Management, Vol. 36 No. 3, pp. 349-359.

Atwood, M. A., Mora, J. W. and Kaplan, A. W. (2010), "Learning to lead: evaluating leadership and organizational learning", Leadership \& Organization Development Journal, Vol. 31 No. 7, pp. 576-595.

Batson, C. D. and Shaw, L. L. (1991), "Evidence for altruism: Toward a pluralism of prosocial motives”, Psychological Inquiry, Vol. 2 No. 2, pp. 107-122. 
Beltrán-Martín, I., Roca-Puig, V., Escrig-Tena, A. and Bou-Llusar, J. C. (2008), "Human resource flexibility as a mediating variable between high performance work systems and performance", Journal of Management, Vol. 34 No. 5, pp. 1009-1044.

Berson, Y., Nemanich, L. A., Waldman, D. A., Galvin, B. M. and Keller, R. T. (2006), "Leadership and organizational learning: A multiple levels perspective", The Leadership Quarterly, Vol. 17 No. 6, pp. 577-594.

Bolino, M. C., Turnley, W. H. and Niehoff, B. P. (2004), "The other side of the story: Reexamining prevailing assumptions about organizational citizenship behavior", Human Resource Management Review, Vol.14 No.2, pp. 229-246.

Bolino, M. C., Klotz, A. C., Turnley, W. H. and Harvey, J. (2013), "Exploring the dark side of organizational citizenship behavior", Journal of Organizational Behavior, Vol. 34 No.4, pp. 542-559.

Brown, J.S. and Duguid, P. (1991), "Organizational learning and communities-ofpractice: toward a unified view of working, learning, and innovation", Organization Science, Vol. 2 No. 1, pp. 40-57.

Brown, M. E. and Treviño, L. K. (2006), "Ethical leadership: A review and future directions", The Leadership Quarterly, Vol. 17 No. 6, pp. 595-616.

Brown, S. R., Brown, M. and Penner, L. A. (2012), Moving beyond self-interest, Oxford University Press, New York.

Camps, J., Alegre, J. and Torres, F. (2011), "Towards a methodology to assess organizational learning capability: A study among faculty members", International Journal of Manpower, Vol. 32 No. 5/6, pp. 687-703.

Camps, J. and Rodríguez, H. (2011), “Transformational leadership, learning, and employability: Effects on performance among faculty members", Personnel Review, Vol. 40 No.4, pp. 423-442.

Chang, C. C., Tsai, M. C. and Tsai, M. S. (2011), "The organizational citizenship behaviors and organizational commitments of organizational members influences the effects of organizational learning", International Journal of Trade, Economics and Finance, Vol. 2 No. 1, pp. 61-66. 
Chiva, R. and Alegre, J. (2008), "Emotional intelligence and job satisfaction: the role of organizational learning capability", Personnel review, Vol. 37 No. 6, pp. 680-701.

Chiva, R., Alegre, J. and Lapiedra, R. (2007), "Measuring organisational learning capability among the workforce", International Journal of Manpower, Vol. 28 No. 3/4, pp. 224-242.

Chiva, R. and Alegre, J. (2009b), "Organizational learning capability and job satisfaction: An empirical assessment in the ceramic tile industry", British Journal of Management, Vol. 20 No. 3, pp. 323-340.

Chuang, Y. T., Church, R. and Zikic, J. (2004), “Organizational culture, group diversity and intra-group conflict. Team Performance Management”, Vol. 10 No. 1/2, pp. 26-34.

Cialdini, R. B., Brown, S. L., Lewis, B. P., Luce, C. and Neuberg, S. L. (1997), "Reinterpreting the empathy-altruism relationship: When one into one equals oneness", Journal of personality and social psychology, Vol. 73 No. 3, pp. 481-494.

Coopey, J. and Burgoyne, J. (2000), "Politics and organizational learning", Journal of Management Studies, Vol. 37 No. 6, pp. 869-886.

Cox, K.B. (1998), "Antecedents and effects of intergroup conflict in the nursing unit", unpublished doctoral dissertation, Virginia Commonwealth University, Richmond, VA.

Cronbach, L. J. (1951), "Coefficient alpha and the internal structure of tests", Psychometrica, Vol. 16 No. 3, pp. 297-334.

Daily, C. M. and Dollinger, M. J. (1992), "An empirical examination of ownership structure in family and professionally managed firms", Family business review, Vol. 5 No. 2, pp. 117-136.

De Dreu, C. K. (2006), "When too little or too much hurts: Evidence for a curvilinear relationship between task conflict and innovation in teams", Journal of Management, Vol. 32 No.1, pp. 83-107.

De Dreu, C. K. (2008), "The virtue and vice of workplace conflict: Food for (pessimistic) thought”, Journal of Organizational Behavior, Vol. 29 No. 1, pp. 5-18. 
De Dreu, C. K. and Beersma, B. (2005), "Conflict in organizations: Beyond effectiveness and performance", European Journal of Work and Organizational Psychology, Vol. 14 No. 2, pp. 105-117.

De Dreu, C. K. and Van Vianen, A. E. (2001), "Managing relationship conflict and the effectiveness of organizational teams", Journal of Organizational Behavior, Vol. 22 No. 3, pp. 309-328.

De Dreu, C. K. and Weingart, L. R. (2003), “Task versus relationship conflict, team performance, and team member satisfaction: a meta-analysis", Journal of applied Psychology, Vol. 88 No. 4, 741-749.

De Dreu, C. K. and West, M. A. (2001), "Minority dissent and team innovation: the importance of participation in decision making”, Journal of applied psychology, Vol. 86 No. 6, 1191-1201.

De Vignemont, F. and Singer, T. (2006), “The empathic brain: how, when and why?", Trends in cognitive sciences, Vol. 10 No. 10, pp. 435-441.

Deluga, R. J. (1995), “The relation between trust in the supervisor and subordinate organizational citizenship behavior”, Military Psychology, Vol. 7 No. 1, pp. 1-16.

DiBella, A. J., Nevis, E. C. and Gould, J. M. (1996), “Understanding organizational learning capability", Journal of Management Studies, Vol. 33 No. 3, pp. 361-379.

Dierksmeier, C. and M. Pirson: 2008, "Freedom and the Modern Corporation", paper Presented at the ISBEE, Capetown, SA.

Dixon, N. (1997), “The hallways of learning”, Organizational Dynamics, Vol. 25 No. 4, pp. 23-34.

Easterby-Smith, M. and Lyles, M. A. (2003), The Blackwell handbook of organizational learning and knowledge management, Blackwell, Oxford, UK.

Eddleston, K. A. and Kellermanns, F. W. (2007), "Destructive and productive family relationships: A stewardship theory perspective", Journal of Business Venturing, Vol. 22 No. 4, pp. 545-565. 
Edmondson, A. (1999), "Psychological safety and learning behavior in work teams", Administrative science quarterly, Vol. 44 No. 2, pp. 350-383.

Edmondson, A. C. and Mogelof, J. P. (2006), "Explaining psychological safety in innovative teams: Organizational culture, team dynamics, or personality?", in L. Thompson, \& H. S. Choi (Eds.), Creativity and innovation in organizational teams, Lawrence Erlbaum Associates, Mahwah, NJ, pp. 109-136.

Fassina, N. E., Jones, D. A. and Uggerslev, K. L. (2008), "Relationship Clean-Up Time: Using Meta-Analysis and Path Analysis to Clarify Relationships Among Job Satisfaction, Perceived Fairness, and Citizenship Behaviors", Journal of Management, Vol. 34 No. 2, pp. 161-188.

Flores, L. G., Zheng, W., Rau, D. and Thomas, C. H. (2012), “Organizational Learning Subprocess Identification, Construct Validation, and an Empirical Test of Cultural Antecedents", Journal of Management, Vol. 38 No. 2, pp. 640-667.

Fornell, C. and Larcker, D. F. (1981), "Evaluating structural equation models with unobservable variables and measurement error", Journal of Marketing Research, Vol. 18 No. 1 , pp. 39-50.

Friedman, R.A., Tidd, S.T., Currall, S.C. and Tsai, J.C. (2000), "What goes around comes around: the impact of personal conflict styles on work conflict and stress", International Journal of Conflict Management, Vol. 11 No. 1, pp. 32-55.

Fry, L. W., Vitucci, S. and Cedillo, M. (2005), "Spiritual leadership and army transformation: theory, measurement, and establishing a baseline", Leadership Quarterly, Vol. 16 No. 5, pp. 835-62.

García-Morales, V. J., Jiménez-Barrionuevo, M. M. and Gutiérrez-Gutiérrez, L. (2012), "Transformational leadership influence on organizational performance through organizational learning and innovation", Journal of Business Research, Vol. 65 No.7, pp. 1040-1050.

Gardner, W. L., Avolio, B. J., Luthans, F., May, D. R. and Walumba, F. O. (2005), "Can you see the real me? A self-based model of authentic leader and follower development", The Leadership Quarterly, Vol. 16 No. 3, pp. 373-394. 
George, J. M. (2013), “Compassion and Capitalism Implications for Organizational Studies”, Journal of Management. DOI: 10.1177/0149206313490028

Gersick, K.E., Davis, J.A., Hampton, M.M. and Lansberg, I. (1997), Generation to Generation: Life Cycles of the Family Business, Harvard Business School Press, Cambridge, MA.

Ghoshal, S. (2005), "Bad management theories are destroying good management practices", Academy of Management Learning \& Education, Vol. 4 No.1, pp. 75-91.

Goh, S. and Richards, G. (1997), "Benchmarking the learning capability of organizations", European Management Journal, Vol. 15 No. 5, pp. 575-583.

Goh, S. C. (2003), "Improving organizational learning capability: lessons from two case studies”, Learning Organization, The, Vol. 10 No.4, pp. 216-227.

Greer, L. L., Jehn, K. A. and Mannix, E. A. (2008), "Conflict Transformation A Longitudinal Investigation of the Relationships Between Different Types of Intragroup Conflict and the Moderating Role of Conflict Resolution”, Small Group Research, Vol. 39 No. 3, pp. 278-302.

Griffith, T., Mannix, E. and Neale, M. (2003), "Conflict and virtual teams", in C. Gibson \& S. Cohen (Eds.), Virtual teams that work: Creating conditions for virtual team effectiveness, San Francisco, Jossey-Bass, CA, pp. 335-352.

Hair, H. F., Anderson, R. E., Tatham, R. L. and Black, W. C. (1998), Multivariate data analysis, Prentice Hall, London.

Hair, H. F., Anderson, R. E., Tatham, R. L. and Black, W. C. (1999), Multivariate data analysis, Prentice Hall, London.

Healy, K. (2004), "Altruism as an organizational problem: The case of organ procurement”, American Sociological Review, Vol. 69 No. 3, pp. 387-404.

Hedberg, B. (1981), "How organizations learn and unlearn", in Nystrom, P.C., Starbuck, W.H. (Eds.), Handbook of Organizational Design, Oxford University Press, London, pp. 8-27. 
Huber, G.P. (1991), "Organizational learning: the contributing processes and the literatures", Organization Science, Vol. 2, pp. 88-115.

Islam, T., Ahmad, Z., Ahmed, I. and Mohammad, S. K. (2012), "Key Factors of organizational citizenship behavior in the banking sector of Pakistan", African Journal of Business Management, Vol. 6 No. 9, pp. 3296-3302.

Jehn, K. A. (1994), "Enhancing effectiveness: An investigation of advantages and disadvantages of value-based intragroup conflict", International Journal of Conflict Management, Vol. 5 No. 3, pp. 223-238.

Jehn, K. A. (1995), "A multimethod examination of the benefits and detriments of intragroup conflict”, Administrative science quarterly, Vol. 40 No. 2, pp. 256-282.

Jehn, K. A. and Bendersky, C. (2003), "Intragroup conflict in organizations: A contingency perspective on the conflict-outcome relationship", Research in organizational behavior, Vol. 25, pp. 187-242.

Jehn, K. A. and Mannix, E. A. (2001), “The dynamic nature of conflict: A longitudinal study of intragroup conflict and group performance", Academy of management journal, Vol. 44 No.2, pp. 238-251.

Jerez-Gómez, P., Céspedes-Lorente, J. and Valle-Cabrera, R. (2007), Organizational learning and compensation strategies: Evidence from the Spanish chemical industry, Global Business and Organizational Excellence, Vol. 26 No. 3, pp. 51-72.

Jerez-Gómez, P., Céspedes-Lorente, J. and Valle-Cabrera, R. (2005), “Organizational learning capability: a proposal of measurement", Journal of Business Research, Vol. 58 No. 6, pp. 715-725.

Kanungo, R. N. and Conger, J. A. (1993), "Promoting altruism as a corporate goal", The Academy of Management Executive, Vol. 7 No. 3, pp. 37-48.

Kaplan, S. (2000), "New ways to promote proenvironmental behavior: Human nature and environmentally responsible behavior", Journal of social issues, Vol. 56 No.3, pp. 491-508.

Karakas, F. (2010), "Spirituality and performance in organizations: A literature review", Journal of business ethics, Vol. 94 No. 1, pp. 89-106. 
Kellermanns, F. W. and Eddleston, K. A. (2004), Feuding families: When conflict does a family firm good, Entrepreneurship Theory and Practice, Vol. 28 No. 3, pp. 209-228.

Korsgaard, M. A., Jeong, S. S., Mahony, D. M. and Pitariu, A. H. (2008), A multilevel view of intragroup conflict, Journal of Management, Vol. 34 No.6, pp. 1222-1252.

Kouzes, J.P. and Posner, B.Z. (1987), The Leadership Challenge: How to get Extraordinary Things done in Organizations, Jossey-Bass, San Francisco.

Lemay Jr, E. P., Clark, M. S. and Feeney, B. C. (2007), "Projection of responsiveness to needs and the construction of satisfying communal relationships", Journal of personality and social psychology, Vol. 92 No. 5, pp. 834-853.

Lepoutre, J. and Heene, A. (2006), "Investigating the impact of firm size on small business social responsibility: a critical review", Journal of business ethics, Vol. 67 No.3, pp. 257-273.

Llorens-Montes, F. J., Ruiz-Moreno, A. and García-Morales, V. J. (2005), "Influence of Support Leadership and Teamwork Cohesion on Organizational Learning, Innovation and Performance: An Empirical Examination”, Technovation, Vol. 25 No. 10, pp. 11591172.

Losada, M. and Heaphy, E. (2004), "The role of positivity and connectivity in the performance of business teams a nonlinear dynamics model”, American Behavioral Scientist, Vol. 47 No. 6, pp. 740-765.

Luque, T. (2000), Técnicas de análisis de datos en investigación de mercados, Madrid, Pirámide, Spain.

Melé, D. (2009), "Editorial introduction: Towards a more humanistic management", Journal of business ethics, Vol. 88 No. 3, pp. 413-416.

Monroe, K. R. (1996), The heart of altruism: Perceptions of a common humanity, Princeton, Princeton University Press, NJ.

Morrison, N. K. and Severino, S. K. (2007), “Altruism: Toward a psychobiospiritual conceptualization”, Zygon, Vol. 42 No.1, pp. 25-40. 
Nooteboom, B., Berger, H. and Noorderhaven, N. G. (1997), "Effects of trust and governance on relational risk", Academy of Management Journal, Vol. 40 No.2, pp. 308-338.

Nunnally, J. C. (1978), Psychometric Theory, McGraw-Hill, New York.

Olson, B. J., Parayitam, S. and Bao, Y. (2007), "Strategic decision making: The effects of cognitive diversity, conflict, and trust on decision outcomes", Journal of Management, Vol. 33 No.2, pp. 196-222.

Organ, D. W. (1988), Organizational citizenship behavior, Lexington, Lexington Books, MA.

Organ, D. W., Podsakoff, P. M. and MacKenzie, S. B. (2006), Organizational citizenship behavior: Its nature, antecedents, and consequences, Sage.

Oswick, C., Anthony, P., Keenoy, T. and Mangham, I.L. (2000), “A dialogic analysis of organizational learning. Journal of Management Studies”, Vol. 37 No. 6, pp. 887-901.

Panteli, N. and Sockalingam, S. (2005), "Trust and conflict within virtual interorganizational alliances: a framework for facilitating knowledge sharing", Decision Support Systems, Vol. 39 No. 4, pp. 599-617.

Pedler, M., Burgoyne, J. and Boydell, T. (1997), The Learning Company: a Strategy for Sustainable Development, McGraw-Hill, Maidenhead.

Piliavin, J. A. and Charng, H. W. (1990), "Altruism: A review of recent theory and research", Annual review of sociology, Vol. 16, pp. 27-65.

Pirson, M. A. and Lawrence, P. R. (2010), "Humanism in business-towards a paradigm shift?”, Journal of Business Ethics, Vol. 93 No. 4, pp. 553-565.

Pirson, M. and Turnbull, S. (2011), "Toward a more humanistic governance model: Network governance structures”, Journal of Business Ethics, Vol. 99 No. 1, pp. 101114.

Podsakoff, P. M. and Organ, D. W. (1986), "Self-reports in organizational research: Problems and prospects", Journal of Management, Vol. 12 No. 4, pp. 531-544. 
Podsakoff, P. M., MacKenzie, S. B., Lee, J. Y. and Podsakoff, N. P. (2003), “Common method biases in behavioral research: A critical review of the literature and recommended remedies", Journal of Applied Psychology, Vol. 88 No. 5, 879-903.

Podsakoff, P. M., MacKenzie, S. B., Moorman, R. H. and Fetter, R. (1990), "Transformational leader behaviors and their effects on followers' trust in leader, satisfaction, and organizational citizenship behaviors", Leadership Quarterly, Vol. 1 No. 2, pp. 107-142.

Popper, M. and Lipshitz, R. (2000), "Organizational learning: mechanism, culture and feasibility", Management Learning, Vol. 31 No. 2, pp. 181-196.

Puffer, S. M. and Meindl, J. R. (1995), "Volunteers from corporations: Work cultures reflect values similar to the voluntary organization's", Nonprofit Management and Leadership, Vol. 5 No.4, pp. 359-375.

Rynes, S. L., Bartunek, J. M., Dutton, J. E. and Margolis, J. D. (2012), "Care and compassion through an organizational lens: Opening up new possibilities", Academy of Management Review, Vol. 37 No. 4, 503-523.

Schulze, W. S., Lubatkin, M. H. and Dino, R. N. (2003), “Toward a theory of agency and altruism in family firms", Journal of Business Venturing, Vol. 18 No. 4, pp. 473490.

Scott-Ladd, B. and Chan, C. C. (2004), "Emotional intelligence and participation in decision making: strategies for promoting organizational learning and change", Strategic Change, Vol. 13 No. 2, pp. 95-105.

Simon, H. A. (1991), "Bounded Rationality and Organizational Learning", Organization Science, Vol. 2 No.1, pp. 125-34.

Simmons, R. G. (1991), “Altruism and Sociology”, Sociological Quarterly, Vol. 32 No. 1, pp. 1-22.

Simons, T. L. and Peterson, R. S. (2000), "Task conflict and relationship conflict in top management teams: the pivotal role of intragroup trust", Journal of applied psychology, Vol. 85 No.1, pp. 102-111. 
Smith, C. A., Organ, D. W. and Near, J. P. (1983), "Organizational citizenship behavior: Its nature and antecedents", Journal of applied psychology, Vol. 68 No. 4, pp. 653-663.

Somashekhar, D. R., Pundhir, S. and Saxena, A. (2011), "Towards more effective relations among employees: A study of altruism among teachers in India", International Journal of Management, Vol. 28 No. 3, pp. 939-944.

Somech, A. and Drach-Zahavy, A. (2004), "Exploring organizational citizenship behaviour from an organizational perspective: The relationship between organizational learning and organizational citizenship behavior", Journal of Occupational and Organizational Psychology, Vol. 77 No. 3, pp. 281-298.

Spector, P. (1992), Summated rating scale construction: An introduction, Newbury Park, Sage, CA.

Spitzeck, H. (2011), "An integrated model of humanistic management", Journal of business ethics, Vol. 99 No. 1, pp. 51-62.

Spreitzer, G., Sutcliffe, K., Dutton, J., Sonenshein, S. and Grant, A. M. (2005), “A socially embedded model of thriving at work", Organization Science, Vol. 16 No. 5, pp. 537-549.

Tannenbaum, S. I. (1997), "Enhancing continuous learning: diagnostic findings from multiple companies", Human Resource Management, Vol. 36 No. 4, pp. 437-452.

Tippins, M. J. and Sohi, R. S. (2003), "It competency and firm performance: Is organizational learning a missing link?”, Strategic Management Journal, Vol. 24 No.8, pp. 745-761.

Ulrich, D., Jick, T. and Von Glinow, M. A. (1993), "High-impact learning: Building and diffusing learning capability”, Organizational Dynamics, Vol. 22 No. 2, pp. 52-66.

Van Emmerik, I. H., Jawahar, I. M. and Stone, T. H. (2005), "Associations among altruism, burnout dimensions, and organizational citizenship behavior", Work \& Stress, Vol. 19 No. 1, pp. 93-100. 
Van Grinsven, M. and Visser, M. (2011), "Empowerment, knowledge conversion and dimensions of organizational learning", Learning Organization, The, Vol. 18 No. 5, pp. 378-391.

Vera, D. and Crossan, M. (2004), "Strategic leadership and organizational learning", Academy of Management Review, Vol. 29 No. 2, pp. 222-240.

Weick, K. E. and Westley, F. (1996), "Organizational learning: affirming an oxymoron", in S. R. Clegg, C. Hardy and W. R. Nord (eds), Handbook of Organizational Studies, Sage, London, pp. 440- 458.

Vigoda-Gadot, E. R. A. N. (2006), “Compulsory citizenship behavior: Theorizing some dark sides of the good soldier syndrome in organizations", Journal for the Theory of Social Behaviour, Vol. 36 No.1, pp. 77-93.

Williams, L. J., Gavin, M. B. and Hartman, N. S. (2004), "Structural equation modeling methods in strategy research: Applications and issues", in Ketchen, D.J. Jr and Bergh; D.D. (Eds.), Research Methodology in Strategy and Management, Elsevier, Oxford, Vol. 1, pp. 303-346.

Yang, J. and Mossholder, K. W. (2004), "Decoupling task and relationship conflict: The role of intragroup emotional processing”, Journal of Organizational Behavior, Vol. 25 No. 5, pp. 589-605.

Yen, H. R. and Niehoff, B. P. (2004), "Organizational citizenship behaviors and organizational effectiveness: Examining relationships in Taiwanese banks", Journal of Applied Social Psychology, Vol. 34 No. 8, pp. 1617-1637. 


\section{Figures}

Figure1. Theoretical model of the research.

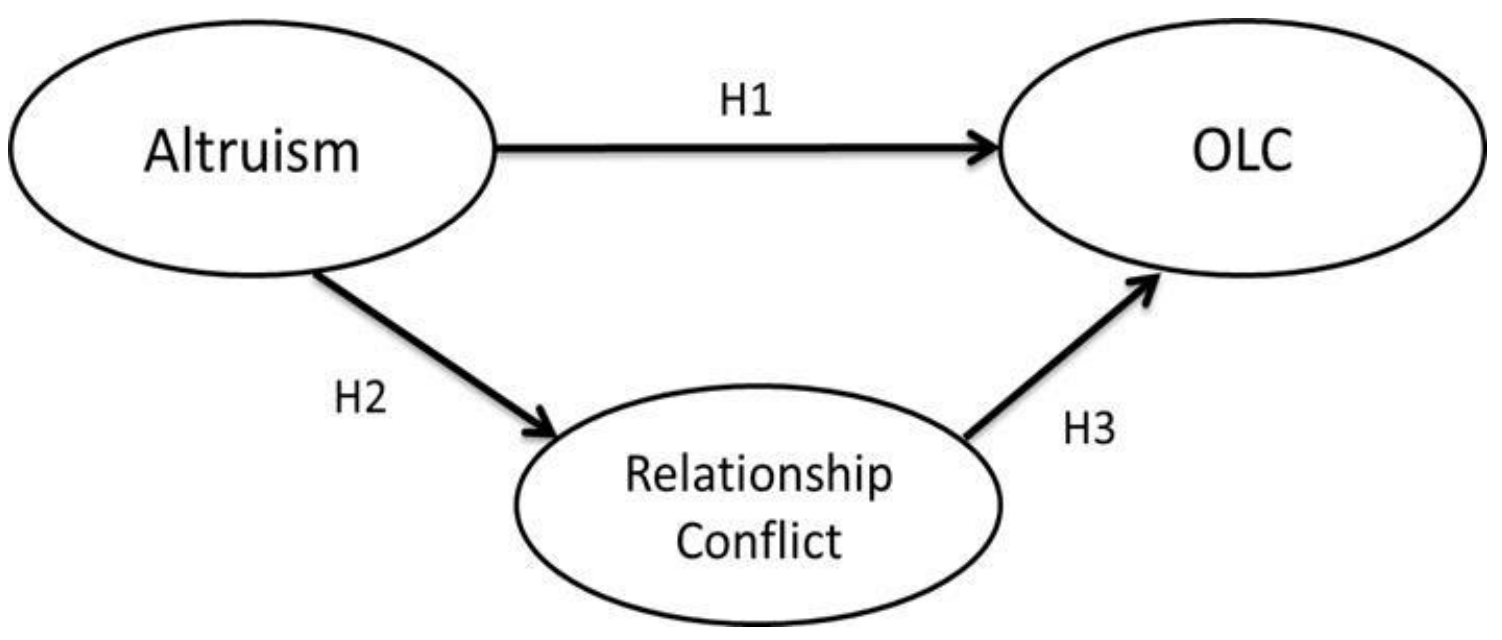

Note: OLC $=$ Organizational learning capability. 
Figure 2. Confirmatory Factor Analyses for Organizational Learning Capability (OLC).

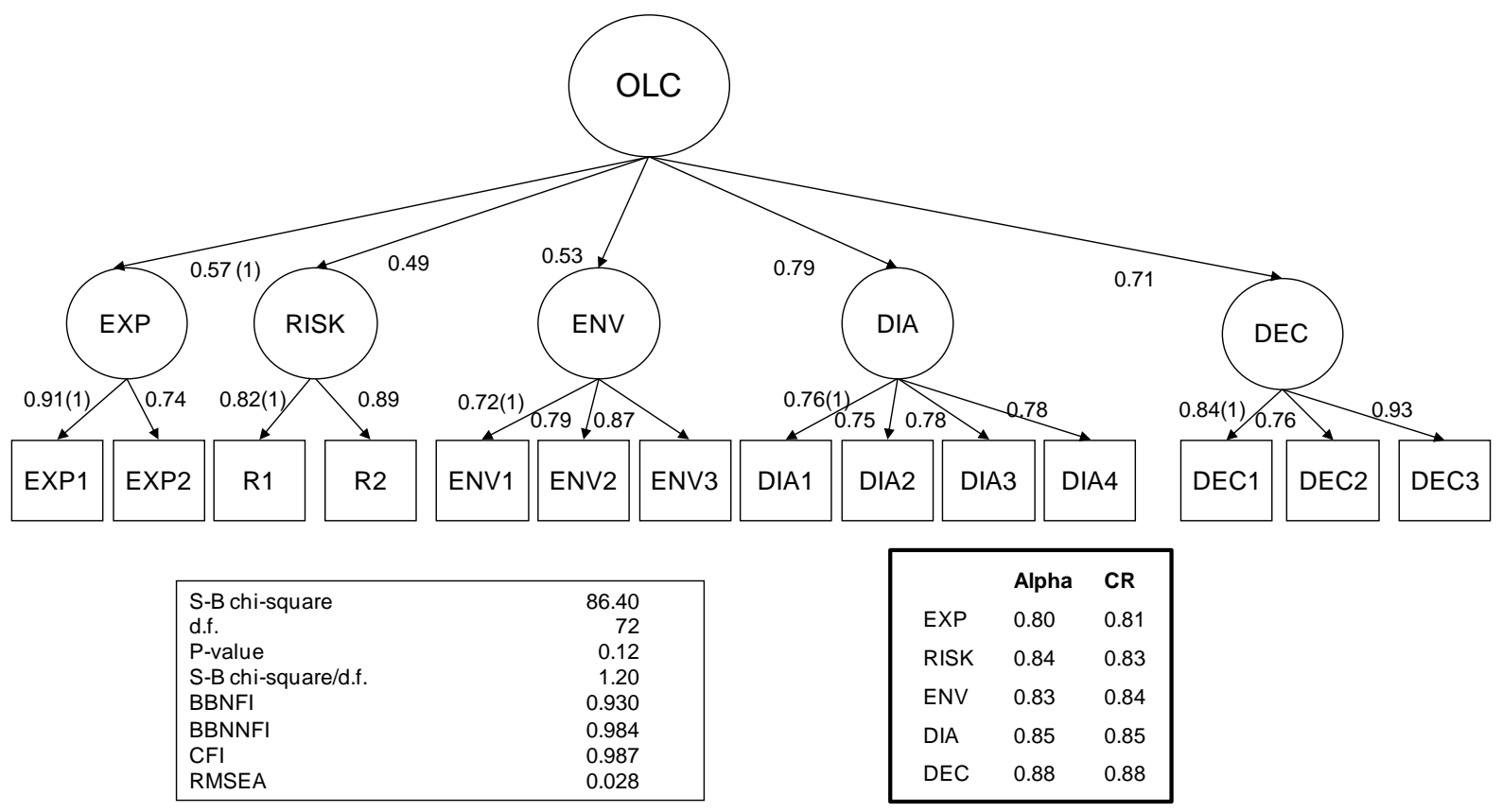

(1)The parameter was equaled to 1 to fix the latent variable scale. Parameter estimates are standardized. All parameter estimates are significant at a $95 \%$ confidence level.

Note: $O L C=$ Organizational learning capability; $E X P=$ Experimentation; $R I S K=$ Acceptance of risk; $E N V=$ Interaction with the external environment $; D I A=$ Dialogue $; D E C=$ Participative decisionmaking. 
Figure 3. Direct effect model: Altruism and organizational learning capability.

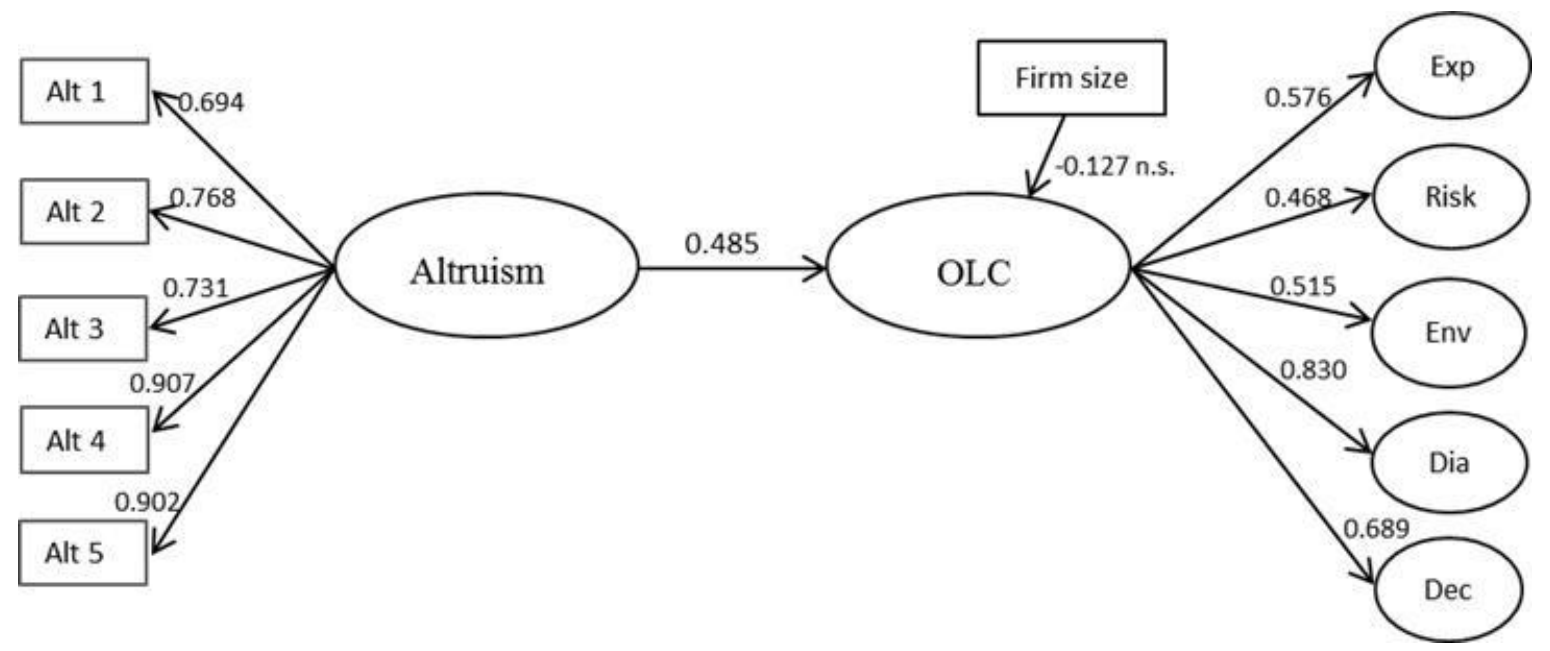

\begin{tabular}{|ll|}
\hline S-B chi-square & 239.858 \\
d.f. & $\mathbf{1 8 4}$ \\
P-value & 0.003 \\
S-B chi-square/d.f. & $\mathbf{1 . 3 0 3}$ \\
BBNFI & $\mathbf{0 . 8 8 1}$ \\
BBNNFI & $\mathbf{0 . 9 6 5}$ \\
CFI & $\mathbf{0 . 9 6 9}$ \\
RMSEA & $\mathbf{0 . 0 3 5}$ \\
\hline
\end{tabular}

(a) Organizational learning capability (OLC) is a second-order factor. For the sake of brevity, only the first-order loadings are shown. The item loadings for these first-order factors are all significant at $\mathrm{p}<0.001$.

Note: $O L C=$ Organizational learning capability; EXP = Experimentation; RISK= Acceptance of risk; $E N V=$ Interaction with the external environment; $D I A=$ Dialogue; $D E C=$ Participative decision-making. 
Figure 4. Mediating effect model: Altruism, organizational learning capability and relationship conflict.

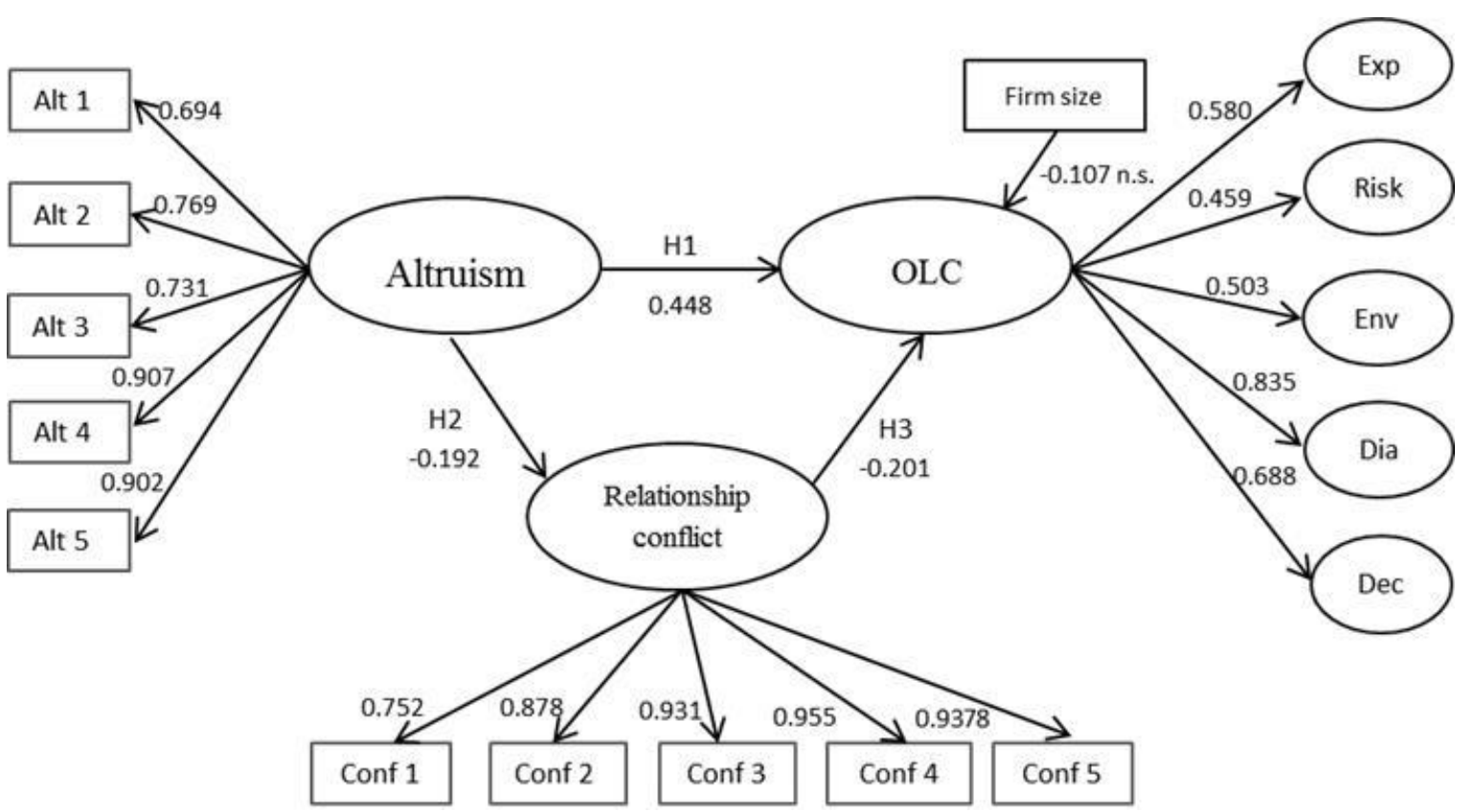

\begin{tabular}{|ll|}
\hline S-B chi-square & 303.048 \\
d.f. & 267 \\
P-value & 0.064 \\
S-B chi-square/d.f. & 1.135 \\
BBNFI & 0.895 \\
BBNNFI & 0.984 \\
CFI & 0.986 \\
RMSEA & 0.023 \\
\hline
\end{tabular}

(a) Organizational learning capability (OLC) is a second-order factor. For the sake of brevity, only the first-order loadings are shown. The item loadings for these first-order factors are all significant at $\mathrm{p}<0.001$.

Note: OLC = Organizational learning capability; EXP = Experimentation; $R I S K=$ Acceptance of risk; $E N V=$ Interaction with the external environment $; D I A=$ Dialogue $; D E C=$ Participative decisionmaking. 


\section{Tables}

Table 1. Correlation factors, means and standard deviation.

\begin{tabular}{|c|c|c|c|c|c|c|c|c|c|}
\hline & Mean & S.D. & $\mathrm{CONF}$ & $\overline{\mathrm{ALT}}$ & EXP & $\overline{\text { RISK }}$ & $\overline{\text { INT }}$ & $\overline{\text { DIA }}$ & TDEC \\
\hline $\begin{array}{l}\text { Relationship } \\
\text { Conflict (CONF) }\end{array}$ & 1.439 & 0.653 & 1 & & & & & & \\
\hline Altruism (ALT) & 3.812 & 0.563 & $-0.183 * *$ & 1 & & & & & \\
\hline $\begin{array}{l}\text { Experimentation } \\
(\text { EXP) }\end{array}$ & 3.990 & 0.563 & $-0.211 * *$ & $0.279 * *$ & 1 & & & & \\
\hline $\begin{array}{l}\text { Acceptance of } \\
\text { risk (RISK) }\end{array}$ & $f_{3.371}$ & 0.852 & -0.061 & $0.171^{* *}$ & $0.312 * *$ & 1 & & & \\
\hline $\begin{array}{l}\text { Interaction with } \\
\text { environment } \\
\text { (INT) }\end{array}$ & 3.692 & 0.673 & -0.061 & $0.156^{*}$ & $0.175^{* *}$ & $0.273 * *$ & 1 & & \\
\hline Dialogue (DIA) & 4.126 & 0.549 & $-0.251 * *$ & $0.413 * *$ & $0.404 * *$ & $0.282 * *$ & $0.345^{* *}$ & 1 & \\
\hline $\begin{array}{l}\text { Taking decisions } \\
\text { (TDEC) }\end{array}$ & $\mathrm{s}_{3.474}$ & 0.676 & $-0.219 * *$ & $0.271 * *$ & $0.331 * *$ & $0.315 * *$ & $0.360 * *$ & $0.495 * *$ & 1 \\
\hline
\end{tabular}

* Significant correlation $(\mathrm{p}<0.05)$

** Significant correlation $(\mathrm{p}<0.01)$

For the standard deviations and correlations between factors, we worked with the mean for the items making up each dimension.

Table 2. Reliability of the measurement scales.

\begin{tabular}{|c|c|c|c|}
\hline Construct & Cronbach's alpha & Composite reliability & $\begin{array}{c}\text { Extracted Mean } \\
\text { variance }\end{array}$ \\
\hline $\begin{array}{l}\text { Relationship Conflict } \\
\text { (5 items) }\end{array}$ & 0.950 & 0.951 & 0.799 \\
\hline Altruism (5 items) & 0.896 & 0.901 & 0.649 \\
\hline $\begin{array}{l}\text { Experimentation }(2 \\
\text { items) }\end{array}$ & 0.802 & 0.810 & 0.684 \\
\hline $\begin{array}{l}\text { Acceptance of risk ( } 2 \\
\text { items) }\end{array}$ & 0.842 & 0.845 & 0.732 \\
\hline $\begin{array}{l}\text { Interaction with the } \\
\text { external environment } \\
\text { ( } 3 \text { items) }\end{array}$ & 0.829 & 0.835 & 0.630 \\
\hline Dialogue (4 items) & 0.849 & 0.851 & 0.589 \\
\hline $\begin{array}{l}\text { Participative } \\
\text { decision-making } \quad(3 \\
\text { items) }\end{array}$ & 0.871 & 0.881 & 0.713 \\
\hline
\end{tabular}


Table 3. Fit indices for the structural models.

\begin{tabular}{|c|c|c|c|c|c|c|}
\hline Model & $\begin{array}{c}\text { Satorra }- \\
\text { Bentler } \\
\text { Chi-Square }\end{array}$ & d.f. & $\mathrm{p}$ & $\begin{array}{c}\text { Bentler-Bonnet } \\
\text { Non-Normed } \\
\text { Fit }\end{array}$ & $\begin{array}{c}\text { Comparative } \\
\text { Fit Index }\end{array}$ & $\begin{array}{c}\text { Root Mean } \\
\text { Square Error of } \\
\text { Approximation }\end{array}$ \\
\hline $\begin{array}{c}\text { Direct effect } \\
\text { model }\end{array}$ & 239.858 & 184 & 0.003 & 0.965 & 0.969 & 0.035 \\
\hline $\begin{array}{c}\text { Mediated } \\
\text { model }\end{array}$ & 303.048 & 267 & 0.064 & 0.984 & 0.986 & 0.023 \\
\hline $\begin{array}{c}\text { Constrained } \\
\text { model }\end{array}$ & 335.547 & 268 & 0.003 & 0.971 & 0.974 & 0.032 \\
\hline
\end{tabular}


Table 4. Structural equations to test the hypothesis that relationship conflict mediates in the relationship between altruism and organizational learning capability.

\begin{tabular}{lc}
\hline Structural equation & $\mathbf{R}^{2}$ \\
\hline Direct effect model & \\
$\begin{array}{l}\mathrm{OLC}=0.485^{*} \mathrm{ALT} \\
(\mathrm{t}=4.125)\end{array}$ & 0.251 \\
\hline $\begin{array}{l}\text { Mediation effect model } \\
\mathrm{OLC}=-0.201^{*} \mathrm{CONF}+0.448^{*} \mathrm{ALT} \\
\quad(\mathrm{t}=-2.202) \quad(\mathrm{t}=4.284) \\
\mathrm{CONF}=-0.192^{*} \mathrm{ALT} \\
(\mathrm{t}=-2.463)\end{array}$ & 0.287 \\
\hline $\begin{array}{l}\text { Note: } \\
\text { Conflict }\end{array}$ & 0.037 \\
\hline
\end{tabular}




\section{Appendix: Research Questionnaire}

Please answer the following questions about your company or organization. Indicate the number corresponding to the answer that best matches your opinion, where 1 represents strongly disagree and 5 , strongly agree.

\begin{tabular}{|l|l|l|l|l|}
\hline $\begin{array}{l}\text { Strongly } \\
\text { disagree }\end{array}$ & Disagree & $\begin{array}{l}\text { Neither agree } \\
\text { nor disagree }\end{array}$ & In accordance & Strongly agree \\
\hline $\mathbf{1}$ & $\mathbf{2}$ & $\mathbf{3}$ & $\mathbf{4}$ & $\mathbf{5}$ \\
\hline
\end{tabular}

About altruism: Podsakoff, MacKenzie, Moorman and Fetter (1990).

\begin{tabular}{|ll|l|}
\hline 1. & Helps others who have been absent. & $1-2-3-4-5$ \\
\hline 2. & Helps others who have heavy workloads. & $1-2-3-4-5$ \\
\hline 3. & Helps orient new people even though it is not required. & $1-2-3-4-5$ \\
\hline 4. & Willingly helps others who have work related problems. & $1-2-3-4-5$ \\
\hline 5. & Is always ready to lend a helping hand to those around him/her. & $1-2-3-4-5$ \\
\hline
\end{tabular}

About conflict: Cox (1998).

\begin{tabular}{|c|c|}
\hline 6. The atmosphere here is often charged with hostility. & $1-2-3-4-5$ \\
\hline 7. Backbiting is a frequent occurrence. & $1-2-3-4-5$ \\
\hline 8. One party frequently undermines another. & $1-2-3-4-5$ \\
\hline 9. There are often feelings of hostility among parties. & $1-2-3-4-5$ \\
\hline 10. Much "plotting" takes place "behind the scenes". & $1-2-3-4-5$ \\
\hline
\end{tabular}

Organizational learning capability: Chiva, Alegre and Lapiedra (2007).

About experimentation:

\begin{tabular}{|l|c|}
\hline $\begin{array}{l}\text { 11. People here receive support and encouragement when presenting new } \\
\text { ideas. }\end{array}$ & $1-2-3-4-5$ \\
\hline $\begin{array}{l}\text { 12. Initiative often receives a favorable response here, so people feel } \\
\text { encouraged to generate new ideas. }\end{array}$ & $1-2-3-4-5$ \\
\hline
\end{tabular}

About Risk taking:

13. People are encouraged to take risks in this organization.

14. People here often venture into unknown territory.

$1-2-3-4-5$

$1-2-3-4-5$

About interaction with the external environment:

\begin{tabular}{|l|c|}
\hline $\begin{array}{l}\text { 15. It is part of the work of all staff to collect, bring back, and report } \\
\text { information about what is going on outside the company }\end{array}$ & $1-2-3-4-5$ \\
\hline $\begin{array}{l}\text { 16. There are systems and procedures for receiving, collating and sharing } \\
\text { information from outside the company. }\end{array}$ & $1-2-3-4-5$ \\
\hline 17. People are encouraged to interact with the environment. & $1-2-3-4-5$ \\
\hline
\end{tabular}


About dialogue:

\begin{tabular}{|l|c|}
\hline 18. Employees are encouraged to communicate. & $1-2-3-4-5$ \\
\hline 19. There is a free and open communication within my work group. & $1-2-3-4-5$ \\
\hline 20. Managers facilitate communication. & $1-2-3-4-5$ \\
\hline 21. Cross-functional teamwork is a common practice here. & $1-2-3-4-5$ \\
\hline
\end{tabular}

About participative decision making:

\begin{tabular}{|l|l|}
\hline $\begin{array}{l}\text { 22. Managers in this organization frequently involve employees in } \\
\text { important decisions. }\end{array}$ & $1-2-3-4-5$ \\
\hline 23. Policies are significantly influenced by the view of employees. & $1-2-3-4-5$ \\
\hline 24. People feel involved in main company decisions. & $1-2-3-4-5$ \\
\hline
\end{tabular}

